\title{
Aggression and Pro-Sociability: Risk and Protective Dynamics in Popularity and Bullying Processes
}

\section{Agresividad y Pro-Sociabilidad: La Dinámica de Riesgo y Protección en los Procesos de Popularidad y Bullying}

\author{
Tatiane de Oliveira Dias and Carolina Lisboa \\ Universidade do Vale do Rio dos Sinos
}

\author{
Silvia Helena Koller and Diogo DeSousa \\ Universidade Federal do Rio Grande do Sul
}

\begin{abstract}
Previous research has shown that positive psychological characteristics can moderate the relationship between aggression and developmental outcomes. This study assessed whether pro-sociability could moderate the association between aggression and victimization, and aggression and popularity. A convenience sample of 253 Brazilian children of low socioeconomic status ( $M$ age $=11.82, S D=$ 1.41) participated in the study. Structural equation modeling showed that the interaction between aggression and pro-social behaviors did not decrease children's chances of being victimized and did not alter the association between aggression and popularity. Aggression seemed to be a predictor of bullying and pro-sociability, of popularity. These results contradict findings from previous studies that showed an association between aggression and positive behaviors such as pro-sociability. More studies are necessary to highlight cultural and contextual differences, comparing these results to those of other Latin American samples.
\end{abstract}

Keywords: aggression, pro-sociability, popularity, schools, bullying

\begin{abstract}
Estudios anteriores han identificado características psicológicas positivas que pueden moderar la relación entre la agresión y los procesos de desarrollo. En esta investigación se evaluó si la prosociabilidad modera la asociación entre agresión y victimización, y agresión y popularidad. Una muestra de conveniencia de 253 niños brasileros de nivel socioeconómico bajo ( $M$ de edad $=11,82, D E$ $=1,41$ ) participaron en el estudio. El análisis de ecuaciones estructurales mostró que la interacción entre la agresividad y la pro-sociabilidad no protege a los niños de sufrir bullying y tampoco modifica la asociación entre agresión y popularidad. La agresión parece haber sido un predictor del bullying y la pro-sociabilidad, de la popularidad. Esos hallazgos difieren de los resultados de estudios anteriores que muestran una asociación entre agresión y comportamientos positivos, como pro-sociabilidad. Más investigaciones son necesarias que permitan destacar las diferencias culturales y contextuales, comparando estos resultados con los de otras muestras latinoamericanas.
\end{abstract}

Palabras clave: agresión, pro-sociabilidad, popularidad, escuelas, bullying

The aim of the present study was to verify to what extent pro-social behavior moderates the association between aggression and bullying as well as between aggression and popularity. The hypotheses were that the association between aggression and bullying is lower among children who are pro-social as compared to others, as well as that the association between aggression and popularity is stronger for pro-social children. Despite the relevance of the processes under consideration-aggression, popularity, pro-sociability, and bullying-, investigations about these phenomena are still relatively rare in Brazil, specifically considering the associations between aggression, pro-social behavior, and popularity. Planning interventions in school settings and clinical treatments aimed to improve youth's mental and social health could be

Tatiane de Oliveira Dias, Master Program in Psychology, and Carolina Lisboa, Graduate Program in Psychology, Universidade do Vale do Rio dos Sinos, São Leopoldo, Brazil; Silvia Helena Koller, Graduate Program in Psychology, and Diogo DeSousa, Master Program in Psychology, Universidade Federal do Rio Grande do Sul, Porto Alegre, Brazil.

Correspondence concerning this article should be addressed to Carolina Lisboa, Departamento de Psicologia, Universidade do Vale do Rio dos Sinos, Av. Unisinos 950, Bairro Cristo Rei, 93022-000, São Leopoldo, RS, Brasil. E-mail: csmacedo@unisinos.br 
supported by findings of studies in this field. The results of the present study were interpreted based on the ecology of human development perspective, as proposed by Urie Bronfenbrenner (1989, 1996, 1999; Bronfenbrenner \& Evans, 2000; Bronfenbrenner \& Morris, 1998).

\section{Aggression}

Researchers have demonstrated the complexity of aggressive behavior, which is not just an exclusively individual process at a cognitive and behavioral level; it is a social behavior influenced by individual and contextual factors, dyadic interactions, group relationships, and the social organization at the group or institutional level (Almeida, Lisboa, \& Caurcel, 2007; Hinde, 1987; Little, Brauner, Jones, Nock, \& Hawley, 2003; Little, Jones, Henrich, \& Hawley, 2003; Salmivalli, Lagerspetz, Björkqvist, Österman, \& Kaukiainen, 1996; Salmivalli \& Voeten, 2004). Aggressive behavior is also influenced by familial models and relationships (Bringiotti, 2000).

Aggression can be defined as any act that intends to damage or harm someone (Ladd \& Burgees, 1999; Loeber \& Hay, 1997). Aggression can take more than one form of expression, depending on its direction and objectives. Aggressive behavior is also related to the hierarchical relationships between the child who assaults and the one who is assaulted, to gender-based characteristics (Coie \& Dodge, 1998), to the specificity of the developmental phase and individual experiences of the child and the socio-historical context (Bronfenbrenner, 1999).

Aggressive behavior can be seen in a confrontational manner, through direct physical and verbal actions, like kicking, hitting, biting, destroying someone else's property, hurting oneself, cursing, provoking, starting discussions, swearing, mocking, threatening, and ridiculing. It can also be expressed in a non-confrontational manner through indirect hostile acts, such as disturbing the environment, making difficult the flow of group activities, spreading rumors or gossips, and damaging another child's reputation (Ladd \& Burgees, 1999; Loeber \& Hay, 1997).

In terms of its functions, aggression can be defined as reactive, when it derives as a response to a dispute that is interpersonal, hostile, and defensive against a behavior that makes it difficult to accomplish an objective. Proactive aggression, on the other hand, occurs most of the time in a voluntary and determined manner. Proactive aggression can represent an anticipation of a response from others and it has been associated with some risks factors, such as internalizing conflict, delinquency, and shyness (Little, Brauner, et al., 2003; Little, Jones, et al., 2003).

Regardless the form that it takes, aggressive conduct can have the aim of reaching goals, such as popularity, superiority, or group domination (Salmivalli et al., 1996; Salmivalli \& Voeten, 2004). Other objectives may be adaptation to context (Bronfenbrenner, 1999) or even conflict resolution (Little, Brauner, et al., 2003; Little, Jones, et al., 2003). Considering these assumptions, the form that the aggression takes, its purpose, and the context where it happens determine if this behavior will be evaluated as successful to reach developmental outcomes, such as popularity, and may provide protection or, on the other hand, will represent losses, such as exclusion, violence, and other risks. In this sense, aggressive behavior can be considered adaptive or maladaptive, according to the circumstances and results within proximal processes.

\section{Victimization}

Victimization between peers, known today as bullying, is considered a subtype of aggression (Olweus, 1993). Its coverage by the main media news has given educational institutions and society the impression of increasing seriousness in these cases (McLaughlin \& Miller, 2008). According to Nansel et al. (2001), 30\% of American children and adolescents have already been involved in bullying as aggressors or victims. A study held by Malta et al. (2010) with 60,973 children and adolescents from 1,453 public and private schools in Brazil showed that $25.4 \%$ of them were victims of bullying; of these youth, $5.4 \%$ referred have been bullied in the last 30 days and another $69.2 \%$ of them were never involved in bullying. Boys referred 
suffering and to be aggressors in bullying (6.0\%) more often than girls did (4.8\%). There was no difference between public (5.5\%) and private schools $(5.2 \%)$ on bullying incidences.

Maltreatment between peers is a social process that originates from interpersonal relationships, in which violence is initiated by part of the peer group, in a determined context, and then is intensified and reinforced by all group members (DeRosier, Cillessen, Coie, \& Dodge, 1994). Victimization can be identified when a child or adolescent suffers violence in a systematic and intentional form, without apparent motives (at least initially), performed through direct or indirect aggressive actions by one or more identified aggressor. It is set through a power imbalance in which the victims cannot stop this behavior or protect themselves, and there is no reciprocity in this kind of interaction (Almeida, Lisboa, \& Caurcel, 2007; Bronfenbrenner, 1996, Olweus, 1993).

Bullying is a complex process and can lead to serious consequences. It can become a stigma and cause behavioral and emotional problems that are difficult to overcome (Hodges, Boivin, Vitaro, \& Bukowski, 1999; Lisboa, Braga, \& Ebert, 2009). Victimization can be a risk factor to development because it can trigger dysfunctional and maladaptive behavior over time (Almeida, 2000; Lisboa \& Koller, 2004).

According to some studies (Hodges, Malone, \& Perry, 1997; Lisboa \& Koller, 2008), in cases of bullying vulnerable children can find an aggressive friend as a form of protection. This can be explained by the assumption that children hesitate to victimize another child who can be defended by an aggressive friend or due to his or her social position in a group. In other words, an aggressive leader may want to defend his or her friends who are at risk, just as a child can join aggressive friends to avoid the risk of being victimized by other peers (Lisboa \& Koller, 2008). Also, youth without reciprocal friends tend to be more aggressive, perhaps because they perceive little proximity with their peers as well as lack of security and support (Lisboa, 2005; Lisboa \& Koller, 2008).

\section{Pro-Sociability}

For Eisenberg $(1982,1992)$ moral pro-social development is the process of obtaining and modifying the judgments and voluntary behaviors directed towards helping other people or groups. The basic motivation is benefiting others without influence, pressure, or the promise of material or social rewards (Eisenberg, 1982, 1992; Eisenberg \& Miller, 1987). Pro-social actions are acts or behaviors that help reaching well-being and give benefits to other people through help, support, or encouragement (Shaffer, 2000). There are few specific studies about pro-sociability conducted in Brazil and some of them have labeled this phenomenon using other terms, such as social competence, socio-cognitive competence, and socially adaptive behavior (Aznar-Farias, 2000; Del Prette, Del Prette, \& Barreto, 2006; Koller, 2004).

Pro-social behavior consists of an interconnected conjunction of voluntary actions and attitudes that contribute to the generation of positive reciprocity, human solidarity, and emotional and mental health development, as well as the reduction of violent behavior (Roche, 2004; Roche \& Sol, 1998). Consistently, a study with children and adolescents in a Brazilian school (Calbo, Busnello, Rigoli, Schaefer, \& Kristensen, 2009) found that pro-social behavior was inversely associated with victimization, which can be seen as a protective factor against bullying. Furthermore, victimization can be understood as a risk factor that reduces the ability of children and adolescents to display pro-social behavior. Children considered pro-social and who maintain reciprocal friendships may be protected from bullying, because pro-social children are generally popular and well accepted by their peers, making bullying difficult to occur (Hartrup, 1983; Lisboa, 2005; Lisboa \& Koller, 2008).

In their investigation, Rodkin, Farmer, Pearl, and Van Acker (2000) emphasized that popular youths can present pro-social (labeled as the models) or aggressive behaviors (the tough ones). These two groups were described by their peers as "good at sports," "pretty/handsome," and "winners." Both their study and the research carried out by Vaillancourt and Hymel (2006) suggest that pro-social characteristics can protect youths from the negative effects of the as- 
sociation between aggression and popularity (reinforced by peer groups). Therefore, it may be necessary to separately consider popularity and pro-social behaviors and its relationship with bullying.

\section{Popularity}

According to some investigators (Bukowski \& Hoza, 1989; Prinstein \& Cillessen, 2003), being popular can be defined as having social status, leadership, and domination over a peer group. This does not necessarily mean being liked by peers. A child's popularity in a peer group can be directly tied to his or her social acceptance, pro-social behavior, and congruence to group and context rules (Lisboa, 2005; Salmivalli et al., 1996). However, Prinstein and Cillessen (2003) observed a direct correlation between aggression and popularity. In their study they found connections between aggressive behavior and the concept of domination or superiority in a group. Other studies (Perry, Kusel, \& Perry, 1988; Salmivalli et al., 1996) showed that victims of bullying were considered the least popular children.

Popularity can be associated with social adjustment indexes, such as well-being and academic success (Rubin, Bukowski, \& Parker, 2006). Studies investigating perceived popularity (Cillessen \& Mayeux, 2004; Cillessen \& Rose, 2005; LaFontana \& Cillessen, 2002) found associations between peer group status and pro-social and aggressive behavior. These data seem paradoxical, but youth who are popular aggressors can be adapted to the ecological context in which they develop (Rose \& Swenson, 2009). This assumption is supported by studies and discussions that emphasize the group effects on individual behaviors resulting in adaptation and adjustment. In other words, aggression can be reinforced by the immediate context, promoting social adjustment (Berger, 2008). Studies showed that aggressive behavior can be normative and also positive to youth's social development and that these aggressive children and adolescents can be popular and accepted in peer groups (Berger \& Rodkin, 2011; Hawley, 2007; Little, Brauner, et al., 2003).

In a study conducted by Rose and Swenson (2009) popular youths who were also aggressive in their relations did not display symptoms of internalizing disorders. This evidence can be explained by intra-group reinforcement: their peers may, out of fear and "respect" to the social power of some youths, not punish or combat aggressive and dominating acts. However, youth displaying direct aggression presented symptoms of internalizing disorders, suggesting greater risks to their development (Rose \& Swenson, 2009). These facts should be examined through the perspective of risk and protection dynamics, considering the different forms and functions of aggression and the impact of these behaviors in the adolescent peer context. Based on these findings, the present study aimed to verify the role of pro-sociability in protecting against individual and group risk factors associated with aggression and bullying-given how these are expressed in dyadic or group relationships. It was hypothesized that aggressive children (at risk) who also present pro-social behaviors (protection) have their chances of being victimized decreased, being perceived as popular (resilience).

\section{Method}

\section{Participants}

A convenience sample was used, participating 253 children between the ages of 9 and 15 $(M=11.82, S D=1.41): 127$ boys and 126 girls from $3^{\text {rd }}$ and $4^{\text {th }}$ grade. They were enrolled in two public schools in South Brazil. All children belonged to a low socioeconomic status, based on the information about their families' income given by the schools. The children's results in the Raven's Progressive Matrices were used as an exclusion criterion, to avoid biases in terms of IQ (cognitive development). 


\section{Instrument}

A Peer Assessment instrument was used, based on the model developed by Rubin, Bukowski, and Parker (1998), and contains nine statements that describe children's behavioral characteristics and indicators of victimization. Participants were asked to write down, next to the statements, the names of the peers that they most associated with the given characteristics. They could write more than one name next to each item. This peer assessment procedure has been widely used worldwide, including Latin-American samples (Berger \& Rodkin, 2011).

Items, descriptive statistics (means and SD), and their loadings for the main variables of this study are shown in Table 1. Reliability estimates using Cronbach's alpha were adequate.

Table 1

Mean, Standard Deviation, Range of Scores, and Factor Loadings of Items and Cronbach's Alpha of the Peer Nomination Scales

\begin{tabular}{llccccc}
\hline \multirow{2}{*}{ Scale } & \multicolumn{1}{c}{ Item } & Mean & $S D$ & $\begin{array}{c}\text { Range of } \\
\text { scores }\end{array}$ & $\begin{array}{c}\text { Factor } \\
\text { loadings }\end{array}$ & $\alpha$ \\
\hline \multirow{2}{*}{ Aggression } & Uses swear words at others & 0.96 & 1.95 & $0-13$ & 0.93 & \\
& $\begin{array}{l}\text { Kicks, hits, and pushes others } \\
\text { Talks badly about others }\end{array}$ & 0.94 & 1.60 & $0-9$ & 0.85 & 0.856 \\
& Perceived & 1.05 & 2.35 & $0-20$ & 0.67 & \\
popularity & Is famous & 1.04 & 1.65 & $0-10$ & 0.89 & 0.679 \\
& Everyone knows him/her & 0.92 & 1.54 & $0-11$ & 0.64 & \\
Pro-sociability & Helps others & & & & & \\
& Wants everyone to be treated in & 0.96 & 1.30 & $0-9$ & 0.73 & 0.759 \\
the same way & 0.94 & 1.23 & $0-9$ & 0.62 & \\
Victimization/ $/$ Is left aside & & & & & & \\
Bullying & Is called names & 0.66 & 1.10 & $0-7$ & 0.78 & 0.768 \\
\hline
\end{tabular}

\section{Procedure}

After the research's objectives were presented and the school directors signed a letter of consent, letters of informed consent were also sent to the students' parents asking for authorization and explaining the research's objectives. After obtaining the parents' authorization and the signature of the informed consent form, the data collection began. The instruments were applied collectively in the classrooms. All the ethical demands and exigencies (as per the Resolution number 196 of the Health Ministry of Brazil [Brasil, Ministério da Saúde, 1996]) were attended. Oral assent from children were also obtained.

\section{Data Analyses}

The data was analyzed through the structural equation modeling (SEM) technique. To conduct these analyses, the constructs of Aggression, Pro-sociability, and Aggression x Pro-sociability were used as the independent variables; Victimization (bullying) and Popularity were used as the dependent variables. 


\section{Results}

A SEM model including as independent variables aggression, pro-sociability, and the interaction of both variables to test for moderation, and victimization and popularity as dependent variables was tested. The results for this model for standardized regression weights and correlations among the independent variables are presented in Figure 1. This model showed mediocre goodness-of-fit indexes: $\mathrm{X}^{2}(27, N=253)=59.88, p<0.001, \mathrm{X}^{2} / d f=2.22$, CFI $=$ 0.95, RMSEA $=0.070,90 \%$ CI $[0.046,0.093]$.

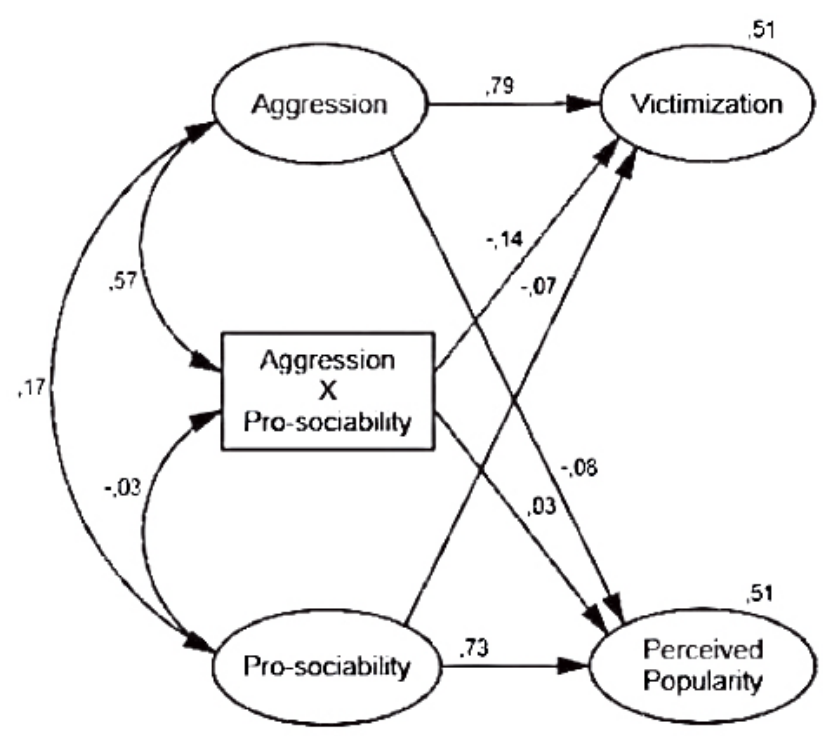

Figure 1. Structural equation model 1, conducted with the interaction Aggression x Pro-sociability. Correlations between independent variables and standardized regression weights are shown.

The interaction between aggression and pro-sociability did not show a significant regression weight for victimization ( $p=0.113$ ) nor for perceived popularity ( $p=0.742$ ), thus, the model showed that pro-sociability did not moderate the association between aggression and bullying or popularity. Therefore, a second model was tested, not including the moderating variable. The results for this model for standardized regression weights and correlations among the independent variables are presented in Figure 2. This model showed adequate adjustment indexes: $\mathrm{X}^{2}(22, N=253)=32.38, p=0.071, \mathrm{X}^{2} / d f=1.47, \mathrm{CFI}=0.98$, RMSEA $=0.043,90 \% \mathrm{CI}$ [0.001, 0.073], and an improvement over the first model $\left(\Delta \mathrm{X}^{2}=27.53, p<0.001\right)$. This model also constitutes an improvement over the null model, $\Delta \mathrm{X}^{2}=627.63, p<0.001$, which adjustment indexes were: $\mathrm{X}^{2}(45, N=253)=660.00, p<0.001, \mathrm{X}^{2} / d f=14.67, \mathrm{RMSEA}=0.233,90 \%$ CI $[0.217$, $0.249]$. Results showed a significant association between aggression and bullying $(p=0.025)$, and between pro-sociability and popularity $(p<0.001)$. 


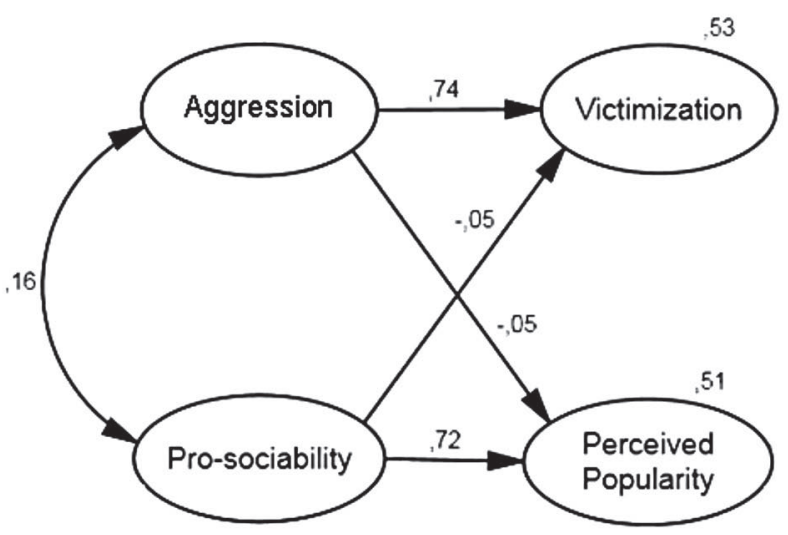

Figure 2. Structural equation model 2, conducted without the interaction Aggression x Pro-sociability. Correlations between independent variables and standardized regression weights are shown.

\section{Discussion}

Contrary to the results found in studies held in the United States, Canada, England, and New Zealand (Bukowski, 2003; Hawley, 2003; Moffitt, 1993), which found a correlation between positive behaviors (for example, leadership and social competence) and aggression, this study did not reveal that pro-sociability moderates the relation between aggression and popularity. In other words, the results do not support the hypothesis that positive behavior moderates the relationship between aggression (risk) and positive results-for example, popularitypromoting the resilience process. This can be in part explained by the cultural differences between the Latin American and North American contexts, although the sample design does not allow drawing generalizations. The difference between the results from other studies and this investigation may be due to macrosystemic factors, but also to cultural aspects and the specific organization and dynamic processes of the school microsystem. It is possible that within the Brazilian culture, popularity has a different impact in peer groups and school communities, being more related to pro-social acts and behaviors than dominance and the instrumental use of aggression to gain power. In other words, an interpretation to these differences between the results of the present study and others held in other countries is that there is cultural and group reinforcement to some specific behaviors. A popular child in Brazil can be prosocial and kind instead of tough and aggressive. Furthermore, the specific aggression form and function investigated could explain the results. In general, studies that identified direct associations between popularity and aggression focused on relational aggression and not on other direct forms of aggression (Rodkin \& Roisman, 2010). These findings suggest that the social adaptation of aggressive children depends not only on their behavior but also on the context and its dynamic influences (Berger \& Rodkin, 2011; Bronfenbrenner, 1996; Maccoby \& Lewis, 2003).

The lack of evidence that a positive characteristic can moderate the association between aggression, popularity, and bullying is supported by contemporary discussions about the importance of ecological and contextual analyses of aggressive behavior. Aggressive behavior is examined at individual and group levels and may result from social and genetic influences that can represent risk and protection, depending on the situation and context (Luthar \& McMahon, 
1996; Moffitt, 1993). Even though the hypothesis was not supported by the data and a positive moderation of risk and resilience was not found, the difference from previous studies should be taken into consideration when trying to clarify the existence of an interaction that is dynamic and not deterministic. Thus, the present study results do not exhaust the discussion, but offer possibilities for reflection on this risk-protection dynamic and also on the association between aggression and pro-sociability. More studies are needed to understand the dynamic process between risk and protective factors in peer groups, since some aspects could minimize and others may maximize the effects of risk and protection.

The findings of this study verify that aggression can be a predictor of victimization amongst peers (bullying), supporting results from previous researches (Bukowski \& Sippola, 2001; Hodges, Card, \& Isaacs, 2003; Lisboa, 2005). Aggressive children can bother their own peers and friends, especially in cases of reactive aggression, making it so that these reactive aggressive youths are victimized (Bukowski \& Sippola, 2001; Hodges et al., 2003). A group may also exclude or victimize a child if he or she unbalances in some way the group's equilibrium and cohesion (Bukowski \& Sippola, 2001; Gavin \& Furman, 1989; Lisboa, 2005). Once more, the different forms and functions of aggressive behavior should be considered. The paradox involving the theme of aggression and the possibility that aggression may be adaptive should also be examined.

According to the present data, pro-sociability seems to be a predictor of popularity, confirming previous studies showing the significant correlation between pro-sociability and the popularity perceived by peers (Lisboa, 2005; Salmivalli et al., 1996). In this sense, children can protect themselves from victimization through pro-social actions, given that these will give them more popularity and, as a consequence, can serve as a form of protection, because it is directly tied to social acceptance and domination in the group (Prinstein \& Cillessen, 2003).

At the same time, the interaction between aggression and pro-sociability was not found to protect from bullying, nor did it encourage popularity. This contradicts the initial hypotheses that the relationship between aggression and pro-sociability could be a predictor of popularity and that the association between aggression and popularity would be more significant for children who were previously pro-social youth. Contradicting previous studies (Hawley, 2003; Little, Brauner, et al., 2003, Little, Jones, et al., 2003), in this research aggression did not correlate with positive behaviors.

For a better and deeper understanding of the similarities and divergences between this research and studies performed in other cultures, the differences and singularities of the context and culture of the participating children of this study should be considered. To do this, more studies are needed to clarify these cultural differences, drawing comparisons with other Latin American samples. Greater depth about the ecological contexts of Brazilian schools is needed. Findings obtained using quantitative data could be broadened and better understood using the methodology of ecological insertion (Paludo \& Koller, 2004).

Considering the importance and influence of schools in the development of children and adolescents, it is important to be aware of the role of this institution in bullying prevention. Aside from acting at an individual, familial, and educational level, the basic needs of children and adolescents in school must be attended, encouraging cooperation, positive relationships, increasing self-esteem, and providing non-aggressive models for conflict resolution (Lisboa et al., 2009).

In addition to focal interventions in schools, public agencies must also be informed in order to develop actions aiming to diminish and control behaviors considered negative to a healthy social environment. It is also important to think on interventions that promote positive conduct, fostering conditions to increase pro-sociability among children, that can also stimulate popularity and friendships, which are processes considered protective factors. Taking into account that the school environment is essential for children's social, cognitive, and emotional development, intensifying protective factors and attenuating risk factors, healthy interpersonal relationships will be favored and social exclusion will be reduced, facilitating the learning process at schools. 
Finally, some limitations of the study undertaken are necessary to mention. One of these refers to the instrument used. As research on these topics-peer relations, pro-sociability, popularity, and the adjustment role of aggression - is still rare in Brazil, there are only a few specific instruments and those that exist are adaptations made to measures developed in other countries. Instruments that could evaluate the different forms and functions of aggression would make possible to drawn more consistent conclusions towards the potential of adaptation of this social behavior and the specific results of this study. Other hypotheses could also be tested, emphasizing, for example, gender differences on these social processes.

\section{References}

Almeida, A. M. T. (2000). As relações entre pares em idade escolar [Peer relations in school age]. Braga, Portugal: Bezerra.

Almeida, A., Lisboa, C., \& Caurcel, M. J. (2007). ¿Por qué ocurren los malos tratos entre iguales?: explicaciones causales de adolescentes portugueses y brasileños. Revista Interamericana de Psicología, 41, 107-118. Retrieved from http://redalyc.uaemex.mx/src/inicio/ArtPdfRed.jsp?iCve=28441201

Aznar-Farias, M. (2000). Prevenção de comportamentos anti-sociais e violentos [Prevention of antisocial and violent behavior]. In Núcleo de Estudos Superiores Transdisciplinares \& Câmara de Comércio e Industria BrasilAlemanha (Orgs.), Anais do Simpósio Internacional da Iniciativa Privada Para a Prevenção da Criminalidade [Proceedings of the International Symposium of Private Initiative for the Prevention of Crime] (pp. 218-236). São Paulo, Brazil: Organizers.

Berger, C. (2008). ¿Es la agresividad adaptativa?: evidencias de su función social en adolescentes chilenos. In C. Berger \& C. Lisboa (Eds.), Violencia escolar: estudios y posibilidades de intervención en Latinoamérica (pp. 139-160). Santiago, Chile: Editorial Universitaria.

Berger, C. \& Rodkin, P. C. (2011). Group influences on individual aggression and prosociality: Early adolescents who change peer affiliations (electronic version). Social Development. doi:10.1111/j.1467-9507.2011.00628.x

Brasil, Ministério da Saúde (1996). Resolução $N^{o} 196$ de 10/10/1996. Brasília, Brazil: Author, Conselho Nacional de Saúde. Retrieved from http://docs.google.com/viewer?a=v\&q=cache:OTdgxkhwO5AJ:conselho.saude.gov.br/ resolucoes/1996/Reso196.doc+http://conselho.saude.gov.br/docs/Resolucoes/Reso196.doc\&hl=es\&gl=cl\&pid=bl\&sr cid=ADGEESjtg0FpLtniGzNGrl6POmwZ00zDeO0qvReGo9xleGCfLIdDOeqyW-xRoprPbH7DnO7VmG-CWrH2P Nf2PwiXRsFEK91tQCzqAv8szQhzsqa6PhwLjMJGan0W8iMtXNSmVYW_UiCZ\&sig=AHIEtbTZi9ys7fmoHXCT EEYCCHeDNByc-w\&pli=1

Bringiotti, M. I. (2000). La escuela ante los niños maltratados. Buenos Aires, Argentina: Paidós.

Bronfenbrenner, U. (1989). Ecological systems theory. Annals of Child Development, 6, 187-249.

Bronfenbrenner, U. (1996). A ecologia do desenvolvimento humano: experimentos naturais e planejados [The ecology of human development: Natural and planned experiments]. Porto Alegre, Brazil: Artes Médicas.

Bronfenbrenner, U. (1999). Environments in developmental perspective: Theoretical and operational models. In D. L. Friedman \& T. D. Wachs (Eds.), Conceptualization and assessment of environment across the life span (pp. 3-30). Washington, DC: American Psychological Association.

Bronfenbrenner, U. \& Evans, G. W. (2000). Developmental science in the $21^{\text {th }}$ century: Emerging questions, theoretical models, research designs and empirical findings. Social Development, 9, 115-125. doi:10.1111/1467-9507.00114

Bronfenbrenner, U. \& Morris, P. (1998). The ecology of developmental processes. In W. Damon \& R. M. Lerner (Eds.), Handbook of child psychology: Vol. 1. Theoretical models of human development ( $5^{\text {th }}$ ed., pp. 993-1027). New York, NY: John Wiley \& Sons.

Bukowski, W. M. (2003). What does it mean to say that aggressive children are competent or incompetent? MerrillPalmer Quarterly, 49, 390-400. doi:10.1353/mpq.2003.0011

Bukowski, W. M. \& Hoza, B. (1989). Popularity and friendship: Issues in theory, measurement, and outcomes. In T. Berndt \& G. Ladd (Orgs.), Peer relations in child development (pp. 15-45). New York, NY: John Wiley \& Sons.

Bukowski, W. M. \& Sippola, L. K. (2001). Groups, individuals, and victimization: A view of the peer system. In S. Graham \& J. Juvonen (Eds.), Peer harassment in school (pp. 355-377). New York, NY: The Guilford Press.

Calbo, A. S., Busnello, F. B., Rigoli, M. M., Schaefer, L. S., \& Kristensen, C. H. (2009). Bullying na escola: comportamento agressivo, vitimização e conduta pró-social entre pares [Bullying at school: Aggressive behavior, victimization, and prosocial behavior among peers]. Contextos Clínicos, 2, 73-80. doi:10.4013/ctc.2009.22.01

Cillessen, A. H. N. \& Mayeux, L. (2004). From censure to reinforcement: Developmental changes in the association between aggression and social status. Child Development, 75, 147-163. doi:10.111/j.1467.8624.2004.0060.x

Cillessen, A. H. N. \& Rose, A. J. (2005). Understanding popularity in the peer system. Current Directions in Psychological Science, 14, 102-105. doi:10.1111/j.0963-7214.2005.00343.x

Coie, J. D. \& Dodge, K. A. (1998). Aggression and antisocial behavior. In W. Damon \& N. Eisenberg (Eds.), Handbook of child psychology: Vol. 3. Social, emotional, and personality development (5 ${ }^{\text {th }}$ ed., pp. 779-862). New York, NY: John Wiley \& Sons. 
Del Prette, Z. A. P., Del Prette, A., \& Barreto, M. C. M. (2006). Treinamento de habilidades sociais em grupo com estudantes de psicologia: avaliando um programa de intervenção [Social skills training in a group of psychology students: Evaluating an intervention program]. In M. Bandeira, Z. A. P. Del Prette, \& A. Del Prette (Eds.), Estudos sobre habilidades sociais e relacionamento interpessoal [Studies on social and interpersonal skills] (pp. 217-234). São Paulo, Brazil: Casa do Psicólogo.

DeRosier, M. E., Cillessen, A. H. N., Coie, J. D., \& Dodge, K. A. (1994). Group social context and children's aggressive behavior. Child Development, 65, 1068-1079. doi:10.1111/j.1467-8624.1994.tb00803.x

Eisenberg, N. (1982). The development of prosocial behavior. New York, NY: Academic Press.

Eisenberg, N. (1992). The caring child. Cambridge, MA: Harvard University Press.

Eisenberg, N. \& Miller, P. A. (1987). Empathy, sympathy, and altruism: Empirical and conceptual links. In N. Eisenberg \& J. Strayer (Eds.), Empathy and its development (pp. 292-316). New York, NY: Cambridge University Press.

Gavin, L. A. \& Furman, W. (1989). Age differences in adolescents' perceptions of their peer groups. Developmental Psychology, 25, 827-834. doi:10.1037/0012-1649.25.5.827

Hartrup, W. W. (1983). Peer relations. In E. M. Hetherington \& P. H. Mussen (Eds.), Handbook of child psychology: Vol. 4. Socialization, personality, and social development $\left(4^{\text {th }}\right.$ ed., pp. 103-196). New York, NY: John Wiley \& Sons.

Hawley, P. H. (2003). Prosocial and coercive configurations of resource control in early adolescence: A case for the welladapted Machiavellian. Merrill-Palmer Quarterly, 49, 279-309. doi:10.1353/mpg.2003.0013

Hawley, P. H. (2007). Social dominance in childhood and adolescence: Why social competence and aggression may go hand in hand. In P. H. Hawley, T. D. Little, \& P. C. Rodkin (Eds.), Aggression and adaptation: The bride side to bad behavior (pp. 1-30). Mahwah, NJ: Lawrence Erlbaum.

Hinde, R. A. (1987). Individuals, relationships and culture: Links between ethology and the social sciences. Cambridge, United Kingdom: Cambridge University Press.

Hodges, E. V. E., Boivin, M., Vitaro, F., \& Bukowski, W. M. (1999). The power of friendship: Protection against an escalating cycle of peer victimization. Developmental Psychology, 35, 94-101. doi:10.1037/0012-1649.35.1.94

Hodges, E. V. E., Card, N. A., \& Isaacs, J. (2003). Learning of aggression in the home and in the peer group. In W. Heitmeyer \& J. Hagan (Eds.), International handbook of violence research (pp. 495-510). Dordrecht, Netherlands: Kluwer Academic Publishers.

Hodges, E. V. E., Malone, M. J., \& Perry, D. G. (1997). Individual risk and social risk as interacting determinants of victimization in the peer group. Developmental Psychology, 33, 1032-1039. doi:10.1037/0012-1649.33.6.1032

Koller, S. H. (2004). Ecologia do desenvolvimento humano: pesquisa e intervenção no Brasil [The ecology of human development: Research and intervention in Brazil]. Porto Alegre, Brazil: Casa do Psicólogo.

Ladd, G. W. \& Burgess, K. B. (1999). Charting the relationship trajectories of aggressive, withdrawn and aggressive/ withdrawn children during early grade school. Child Development, 70, 910-929. doi:10.1111/1467-8624.00066

LaFontana, K. M. \& Cillessen, A. H. N. (2002). Children's perceptions of popular and unpopular peers: A multimethod assessment. Developmental Psychology, 38, 635-647. doi:10.1037/0012-1649.38.5.635

Lisboa, C. S. M. (2005). Comportamento agressivo, vitimização e relações de amizade de crianças em idade escolar: fatores de risco e proteção [Aggressive behavior, victimization, and friendly relations of school-age children: Risk and protective factors] (Unpublished Doctoral Thesis), Universidade Federal do Rio Grande do Sul, Porto Alegre, Brazil.

Lisboa, C., Braga, L. L., \& Ebert, G. (2009). O fenômeno bullying ou vitimização entre pares na atualidade: definições, formas de manifestação e possibilidades de intervenção [The actual phenomenon of bullying or peer victimization: Definitions, manifestation forms, and intervention possibilities]. Contextos Clínicos, 2, 59-71. doi:10.4013/ ctc.2009.21.07

Lisboa, C. \& Koller, S. H. (2004). Interações na escola e processos de aprendizagem: fatores de risco e proteção [Interactions in school and learning processes: Risk and protective factors]. In J. A. Bzuneck \& E. Boruchovitch (Eds.), Aprendizagem: processos psicológicos e contexto social na escola [Learning: Psychological processes and social context in school] (pp. 201-224). Petrópolis, Brazil: Vozes.

Lisboa, C. \& Koller, S. H. (2008). Factores protectores y de riesgo para la agresividad y victimización en escolares brasileños: el rol de los amigos. In C. Berger \& C. Lisboa (Eds.), Violencia escolar: estudios y posibilidades de intervención en Latinoamérica (pp. 161-181). Santiago, Chile: Editorial Universitaria.

Little, T. D., Brauner, J., Jones, S. M., Nock, M. K., \& Hawley, P. H. (2003). Rethinking aggression: A typological examination of the functions of aggression. Merrill-Palmer Quarterly, 49, 343-369. doi:10.1353/mpg.2003.0014

Little, T. D., Henrich, C. C., Jones, S. M., \& Hawley, P. H. (2003). Disentangling the "whys" from the "whats" of aggressive behavior. International Journal of Behavioral Development, 27, 122-133. doi:10.1080/016502502440 00128

Loeber, R. \& Hay, D. (1997). Key issues in the development of aggression and violence from childhood to early adulthood. Annual Review of Psychology, 48, 371-410. doi:10.1146/annurev.psych.48.1.371

Luthar, S. S. \& McMahon, T. J. (1996). Peer reputation among inner-city adolescents: Structure and correlates. Journal of Research on Adolescence, 6, 581-603.

Maccoby, E. E. \& Lewis, C. C. (2003). Less day care or different day care? Child Development, 74, 1069-1075. doi:10.1111/1467-8624.00592

Malta, D. C., Silva, M. A. I., Mello, F. C. M., Monteiro, R. A., Sardinha, L. M. V., Crespo, C. ... Porto, D. L. (2010). Bullying nas escolas brasileiras: resultados da Pesquisa Nacional de Saúde do Escolar (PeNSE) 2009. [Bullying in Brazilian schools: Results of the National School Health Research], 2009. Ciência e Saúde Coletiva, 15 (supl. 2), 3065-3076. 
McLaughlin, J. R. \& Miller, T. W. (2008). Prevention of school violence: Directions, summary, and conclusions. In T. W. Miller (Ed.), School violence and primary prevention (pp. 431-444). New York, NY: Springer. doi:10.1007/9780-387-77119-9

Moffitt, T. E. (1993). Adolescence-limited and life-course-persistent antisocial behavior: A developmental taxonomy. Psychological Review, 100, 674-701. doi:10.1037/0033-295X.100.4.674

Nansel, T. R., Overpeck, M., Pilla, R. S., Ruan, W. J., Simons-Morton, B., \& Scheidt, P. (2001). Bullying behaviors among US youth: Prevalence and association with psychosocial adjustment. JAMA: The Journal of the American Medical Association, 285, 2094-2100. doi:10.1001/jama.285.16.2094

Olweus, D. (1993). Bullying at school: What we know and what we can do. London, United Kingdom: Blackwell.

Paludo, S. \& Koller, S. H. (2004). Inserção ecológica no contexto da rua [Ecological insertion on the street context]. In S. H. Koller (Org.), Ecologia do desenvolvimento humano: pesquisa e intervenção no Brasil [The ecology of human development: Research and intervention in Brazil] (pp. 219-244). Porto Alegre, Brazil: Casa do Psicólogo.

Perry, D. G., Kusel, S. J., \& Perry, L. C. (1988). Victims of peer aggression. Developmental Psychology, 24, 807-814. doi:10.1037/0012-1649.24.6.807

Prinstein, M. J. \& Cillessen, A. H. (2003). Forms and functions of adolescent peer aggression associated with high levels of peer status. Merrill-Palmer Quarterly, 49, 310-342. doi:10.1353/mpg.2003.0015

Roche, R. (2004). Inteligencia prosocial: educación de las emociones y valores. Barcelona, Spain: Universitat Autònoma de Barcelona.

Roche, R. \& Sol, N. (1998). Educación prosocial de las emociones, valores y actitudes positivas: para adolescentes en entornos familiares y escolares. Barcelona, Spain: Blume.

Rodkin, P. C., Farmer, T. W., Pearl, R., \& Van Acker, R. (2000). Heterogeneity of popular boys: Antisocial and prosocial configurations. Developmental Psychology, 36, 14-24. doi:10.1037/0012-1649.36.1.14

Rodkin, P. C. \& Roisman, G. I. (2010). Antecedents and correlates of the popular-aggressive phenomenon in elementary school. Child Development, 81, 837-850. doi:10.1111/j.1467.8624.2010.01437.x

Rose A. J. \& Swenson L. P. (2009). Do perceived popular adolescents who aggress against others experience emotional adjustment problems themselves? Developmental Psychology, 45, 868-872. doi: 10.1037/a0015408

Rubin, K. H., Bukowski, W., \& Parker, J. G. (1998). Peers interactions, relationships, and groups. In W. Damon \& N. Eisenberg (Eds.), Handbook of child psychology: Vol. 3. Social, emotional, and personality development ( $5^{\text {th }}$ ed., pp. 619-700). New York, NY: John Wiley \& Sons.

Rubin, K. H., Bukowski, W. M., \& Parker, J. G. (2006). Peer interactions, relationships, and groups. In W. Damon, R. M. Lerner, \& N. Eisenberg (Eds.), Handbook of child psychology: Vol. 3. Social, emotional, and personality development ( $6^{\text {th }}$ ed., pp. 571-645). New York, NY: John Wiley \& Sons.

Salmivalli, C., Lagerspetz, K., Björkqvist, K., Österman, K., \& Kaukiainen, A. (1996). Bullying as a group process: Participant roles and their relations to social status within the group. Aggressive Behavior, 22, 1-15. doi:10.1002/ (SICI) 1098-2337(1996)22:1<1::AID-AB1>3.0.CO;2-T

Salmivalli, C. \& Voeten, M. (2004). Connections between attitudes, group norms, and behaviour in bullying situations. International Journal of Behavioral Development, 28, 246-258. doi:10.1080/01650250344000488

Shaffer, D. R. (2000). Social and personality development. Belmont, CA: Wadsworth, Cengage Learning.

Vaillancourt, T. \& Hymel, S. (2006). Aggression and social status: The moderating roles of sex and peer-valued characteristics. Aggressive Behavior, 32, 396-408. doi:10.1002/ab.20138

Fecha de recepción: Mayo de 2011.

Fecha de aceptación: Octubre de 2011. 